had boen issuod for fruit and vegetables to be washed and bread containing activated charcoal had been issued.

G. W. Clare gave a short history of the development of the decontamination service at Harwell. The building and plant, now in use, had paid for itself in only two years when costed on equipment which had been saved and put back into service. They moved everything by overhead tackle, which was much more satisfactory than trucking, and grid floors, with all services below, had been very successful. The centre is adjacent to the Active Waste Disposal Building and carries its own trained staff.
C. N. Davies

\title{
STRUCTURE AND FUNCTION OF LIPID-CONTAINING SYSTEMS
}

\section{A} JOINT meeting of the British Biophysical Society and the Biochemical Society attracted more than 200 participants to the University of Birmingham during April 20-21. A comprehensive survey of research relating to lipids and cell mombranes was undertaken in three sessions devoted to physical chemistry of lipid systems, composition and molecular structure of cell membranes, and the role of lipid in membrane activity.

An introductory talk by Dr. D. G. Dervichian on the general theme of the symposium was followed by 20 papers.

Information derived from X-ray diffraction (V. Luzzati) and infra-red spectroscopy (D. Chapman) served to emphasize the liquid crystalline nature of lipid layers under a variety of conditions and the complexity of phase relationships in mixed lipid systems. D. A.ttwood and L. Saunders, and D. B. Gammack, discussed the characteristics of dispersions of lipid in water as examined by lightscattering techniques, and A. D. Bangham and D. A Haydon the interpretation of birefringence measurements. J. A. Lucy and M. Glauert presented a molecular inter. pretation of their electron micrographs of negatively stained lipid preparations and diseussed its possible significance in relation to coll membrane structure.

A review by G. M. Gray of data on the compositions of a variety of cell membranos was followed by a report on the lipid components of membranous fractions from brain homogenates by J. Eichberg and R. M. C. Dawson. B. R. Malcolm presented evidence for the $\alpha$-helical con- figuration in protein layers at air-water interfaces and A. A. Eddy and P. Johns speculated about the possible arrangements of lipoprotoin sub-units in the red cell membrane. J. B. Finean summarized present views on the molecular structure of cell membranes and N. R. Silvester discussed the analysis of the romarkably detailed $\mathrm{X}$-ray diffraction patterns obtained from membrane material derived from eilia. P. F. Millington spoke of the various factors which influenced the widths and densities of lines which characterize cell membranes in electron micrographs, and R. Dourmashkin discussed correlations between the number of sites of interaction of immuno complexes with the surface of the red cell as seen in electron micrographs and the rate of lysis of the cells.

In the final session, J. N. Hawthorne undertook an assessment of present ideas on the role of individual phospholipid components in ion transport and A. D. Bangham and J. C. Watkins suggested that their obsorvations on the accumulation of ions inside lipid micelles might have some relovance to this problem. G. Hübscher discussed the problems associated with the assessment of the infuence of lipid components on the activities of enzyme systems and A. Martinosi presented biochemical and electron microscope data rolating to the inactivation and reactivation of muscle microsomes by removal and rostoration of the lecithin components. L. L. M. van Deenen summarized a variety of data relating to the metabolism of phospholipid fatty acids in cell membranes.

J. B. Finean

\section{RESEARCH EXPENDITURE AND INDUSTRY}

$I^{N}$ his presidential address to the twentieth annual general meeting of the Institution of Metallurgists on May 13, Dr. L. Rotherham dealt with the interrelationship of the growth of numbers of qualified scientists and technologists, the national economy as a whole, productivity and the proper expenditure on research and development. As such, his address was a noteworthy contribution. Although obviously directed to the metallurgist in the first place, it is worthy of close study by all concerned with the more general problems.

The new industries, such as electronics and man-made fibres, havo achieved commercial success by exploiting scientific and technological advances and in the process have ploughed back large sums for increasingly expensive researches. Thus during a period of time they have been able to produce and sell a succession of products. In contrast, some of the older industries have been relatively slow to adopt new techniques though the pace will probably quicken in the next fow years. The danger is that they will not put aside the money required to develop overbetter processes and products. In 1962 industry employed some 9 qualified men per $£$ I million of 'gross domostic product' outside the research and development depart. ments. In 1956 it had been 7.9, and on the basis of a 4 per cent economic growth and what appears to be a reasonably steady figure of 10.5 qualified men per $£ 1$ million of 'gross domestic product', an additional 100,000 scientists and technologists mav expect to find employment in industry between 1962 and 1970 . If all omployers, even the smaller, were to raise the number of 'qualified men' (that is, those with degrees, diplomas and those who take the examinations of professional institutions) employed to that of the highest percentage, almost half as many more would be needed. This increased number of scientists and technologists is seen by Dr. Rotherham as being increasingly provided by university graduates.

In 1961-62 about one-fifth of Britain's total qualified men were engaged on research and development, and if this ratio remains constant, between 1962 and 1970 , about 25,000 extra people will be required. The annual cost, on the average, is of the order of $£ 11,000$ per man engaged in such work, and for this increase a rise in productivity of some 3.8 per cent would suffice. The calculation, however, depends on the assumptions that research expenditure remains at the 1961-62 level of 2.7 per cent of the 'gross domestic product' and that research costs per man do not increase by more than 3 per cent per annum. In Dr. Rotherham's opinion, it might be prudent at this time to raise the percentage of the 'gross domestic product' devoted to research in order to counterbalance any shortfall in productivity, say, to 3 per cent (the American figure is already more than this). After making the usual allowances for rising costs, this should provide for an extra 6,000 research workers per annum. The 